University of New Hampshire

University of New Hampshire Scholars' Repository

Data Catalog

2021

\title{
New Hampshire Continental Shelf Geophysical Database: 2016-2017 Field Campaign - Seafloor Photographs
}

\author{
Larry G. Ward \\ University of New Hampshire CCOM/JHC, Durham, Igward@ad.unh.edu \\ Rachel C. Morrison \\ University of New Hampshire CCOM, Durham \\ Zachary S. McAvoy \\ University of New Hampshire CCOM, Durham
}

Follow this and additional works at: https://scholars.unh.edu/data_series

Part of the Geology Commons, Oceanography Commons, and the Sedimentology Commons

\section{Recommended Citation}

Ward, L.G., Morrison, R.C., and McAvoy, Z.S., 2021, New Hampshire Continental Shelf Geophysical Database: 2016-2017 Field Campaign - Seafloor Photographs. University of New Hampshire Center for Coastal and Ocean Mapping/Joint Hydrographic Center (CCOM/JHC), 24 Colovos Road, Durham, NH 03824. UNH Scholars Repository https://dx.doi.org/10.34051/d/2021.5

This Data Set is brought to you for free and open access by University of New Hampshire Scholars' Repository. It has been accepted for inclusion in Data Catalog by an authorized administrator of University of New Hampshire Scholars' Repository. For more information, please contact Scholarly.Communication@unh.edu. 


\title{
New Hampshire Continental Shelf Geophysical Database: 2016-2017 Field Campaign - Seafloor Photographs
}

\author{
Larry G. Ward, Rachel C. Morrison, and Zachary S. McAvoy \\ Center for Coastal and Ocean Mapping/Joint Hydrographic Center (CCOM/JHC) \\ University of New Hampshire \\ 24 Colovos Road \\ Durham, NH 03824
}

Contact: Larry G. Ward (larry.ward@unh.edu)

\section{Citation:}

The data presented here is freely available. However, please cite the following reference when using:

Ward, L.G., Morrison, R.C., and McAvoy, Z.S., 2021, New Hampshire Continental Shelf Geophysical Database: 2016-2017 Field Campaign - Seafloor Photographs. University of New Hampshire Center for Coastal and Ocean Mapping/Joint Hydrographic Center (CCOM/JHC), 24 Colovos Road, Durham, NH 03824. UNH Scholars Repository (https://scholars.unh.edu)

\section{Acknowledgements:}

The development of this database was supported by the University of New Hampshire/National Oceanic and Atmospheric Administration Joint Hydrographic Center Award Number NA15NOS4000200 and the Bureau of Ocean Energy Management Award Number M14AC00010.

\section{Introduction:}

The "New Hampshire Continental Shelf Geophysical Database: 2016-2017 Field Campaign - Seafloor Photographs" was developed by the University of New Hampshire (UNH) Center for Coastal and Ocean Mapping/Joint Hydrographic Center (CCOM/JHC). The field campaign was conducted to provide ground truth for surficial geology maps for the continental shelf off New Hampshire (NH) and focused on the inner shelf between the coast and the Isles of Shoals. Station locations were chosen where high-resolution bathymetry was available, including multibeam echosounder (MBES) surveys conducted by the UNH CCOM/JHC Hydrographic Field Course (Ocean Engineering 972), MBES surveys by the NOAA National Ocean Service (NOS), and a topo-bathy lidar (Shoals) survey by the United States Geological Survey (USGS) (see Ward et al., 2021c for details). In total, seafloor videography was collected at 151 stations and 855 photographs were extracted from the video. In addition, 150 sediment samples were collected from 85 of the stations and analyzed for grain size. The bottom sediment grain size data is available in Ward et al. (2021c) and at the University of New Hampshire Scholars Repository (see Ward et al., 2021a).

The photographs and locations can also be viewed at the CCOM/JHC website "New Hampshire Continental Shelf: High-Resolution Surficial Geology Maps and Interactive Database" (see Ward et al., 2021b).

\section{Photograph Archives:}

The photographs extracted from the seafloor videography are grouped into four geographic regions: Nearshore York Harbor to Portsmouth Harbor, Nearshore Portsmouth Harbor to Hampton Harbor Inlet, Nearshore Hampton Harbor Inlet to Salisbury Beach, and Offshore to the Isles of Shoals. Location maps are provided for the entire study area and for each of these regions, with stations labeled for reference. These maps are provided in Layout GeoTIFF format containing spatial reference information for the option 
to import and view in a GIS. Each region also contains a Microsoft Excel file with metadata for each photograph, including station identification, geographic location (latitude and longitude), water depth, and a description of the seafloor where video was collected.

\section{Field Methods and Camera System:}

Sampling during the 2016-2017 field campaign was done using the UNH Research Vessel Gulf Surveyor, a $19 \mathrm{~m}$ twin screw aluminum catamaran. The seafloor videography was obtained at each station with a fabricated drop camera consisting of a Delta Vision camera frame mounted $0.4 \mathrm{~m}$ from the seafloor when in its vertical position (Pe'eri et al., 2013). The base of the frame was $0.3 \mathrm{~m}$ by $0.3 \mathrm{~m}$ and was marked in 2 $\mathrm{cm}$ increments on all four sides for scale. The camera had a $1.2 \mathrm{~mm}$ pixel resolution. The camera system was lowered by hand to the seafloor and took video while alternating between drifting and touching down on the bottom. The ship's global navigation satellite system (GNSS) was recorded during sampling and marked each time the seafloor was in contact with the camera frame (touchdowns) or when the camera framework was on its side (tipped), providing a plain view and profile view of the seafloor, respectively. A VLC media player was utilized to extract photographs of the seafloor from the video. Positions determined from the RTK or post-processed GNSS have a position uncertainty on the order of meters for the research vessel. However, for bottom samples the GNSS antenna offset has to be considered, as well as the orientation of the boat. Additionally, the drift of the boat and the drag on the camera must be considered for seafloor videography and photographs. The total estimated error for videography and photographs locations is conservatively estimated to be $\sim 50 \mathrm{~m}$.

\section{References:}

Pe'eri, S., McLeod, A., Lavoie, P., Ackerman, S., Gardner, J., and Parrish, C., 2013, Field calibration and validation of remote-sensing surveys: International Journal of Remote Sensing 34(18): 6423-6436. (https://www.tandfonline.com/doi/full/10.1080/01431161.2013.800655)

Ward, L.G., Morrison, R.C., and McAvoy, Z.S., 2021a, New Hampshire Continental Shelf Geophysical Database: 2016-2017 Field Campaign - Stations and Sediment Data. University of New Hampshire Center for Coastal and Ocean Mapping/Joint Hydrographic Center (CCOM/JHC), 24 Colovos Road, Durham, NH 03824. UNH Scholars Repository (https://dx.doi.org/10.34051/d/2021.2)

Ward, L.G., McAvoy, Z.S., Johnson, P., and Morrison, R., 2021b, New Hampshire Continental Shelf: HighResolution Surficial Geology Maps and Interactive Database, University of New Hampshire Center for Coastal and Ocean Mapping and Joint Hydrographic Center, Durham.

(https://maps.ccom.unh.edu/portal/apps/webappviewer/index.html?id=28df035fe82c423cb3517295d9 $\underline{\mathrm{bbc} 24 \mathrm{c})}$

Ward, L.G., McAvoy, Z.S., Vallee-Anziani, M., and Morrison, R.C., 2021c, Surficial Geology of the Continental Shelf off New Hampshire: Morphologic Features and Surficial Sediment: BOEM/New Hampshire Cooperative Agreement (Contract M14ACO0010) Technical Report, Department of Interior, Bureau of Ocean Energy Management, Marine Minerals Division, 45600 Woodland Road, Sterling, VA, 20166, 184pp. https://dx.doi.org/10.34051/p/2021.31 